CONCEPTIONS OF STATE AND KINGSHIP IN SOUTHEAST ASIA 

CONCEPTIONS OF STATE AND KINGSHIP IN SOUTHEAST ASIA

(Revised version of an article published in THE FAR EASTERN QUARTERLY

Vol. 2, pp. 15-30, November 1942)

by

Robert Heine-Geldern

Data Paper: Number 18

Southeast Asia Program Publications

640 Stewart Avenue

Ithaca, New York 14850

April, 1956 
- Southeast Asia Program, 1956

ISBN 0-87727-018-X

Ninth Printing

April 2004 
Professor Robert Heine-Geldern of the University of Vienna is clearly the doyen of all anthropologists specializing in the whole region to which he himself has helped attach the label of "Southeast Asia." His broad anthropological training, his acute scholarship, and his deep humanistic interests have been devoted almost entirely to this area for forty very productive years. The section on "Sudostasian", almost three hundred pages in length, which he contributed in 1923 to the second volume of Georg Buschan's Illustrierte Volkerkunde is still, in spite of much outdating, the best avaitable detailed account of the prehistoric and historic physical, linguistic, and cultural types of this anthropologically significant but complex part of Asia. His early definition of the Southeast Asian culture area as extending from Assam eastwards to include aboriginal Taiwan and from Southern China southwards through the Indian archipelago stands among anthropologists today. For the island world he adopted the Greek term "Indonesia", first advanced in the 1860's by the German anthropologist Bastian, later incorporated into the Malayo-Polynesian languages of the East Indies (although its use there was forbidden by the Dutch), and now the name of the sixth most populous nation of the world. This recognition of ethnographic Indonesia as a part of Southeast Asia has helped anthropologists understand some of the basic cultural similarities which existed in the region before it was influenced by Chinese, Indic, Moslem and North Atlantic civilizations.

The present paper by Dr. Heine-Geldern is an interesting contribution to an aspect of the political development of this region under influences coming particularly from or through India. The paper has been used at Cornell University as an assigned reading in courses on Southeast Asia since its first publication in The Far Eastern Quarterly. Now with the very kind editorial permission of the Far Eastern Association and of Dr. Heine-Geldern, and with a few minor changes incorporated at the suggestion of the author, the paper is issued by the Cornell Southeast Asia Program in the hope that it may be found useful in the increasing number of courses being given on this area in academic institutions.

This forewardeisevritten with a special sense of gratitude by the undersigned, who began his anthropological studies of Southeast Asia in Vienna in 1930 under Dr. Heine-Geldern's able guidance. To a fine scholar and teacher who has done so much for Southeast Asian studies in America as elsewhere, sincere personal and professional thanks are offered.

Lauriston Sharp, Director Southeast Asia Program

Department of Far Eastern Studies

Cornell University

Ithaca, New York

Apri 1, 1956 
TABLE OF CONTENTS

Page

Macrocosmos and Microcosmos ................ 1

Relation Between State and Universe........... 2

The Capital as the Magic Center of Empire . . . . . . . . . 3

The Lay-Out of Angkor Thom . . . . . . . . . . . 4

The Capital of Burma ................. 5

Cosmic Roles of King, Court and Government ......... 6

Influence on Coronation Ritual ............ 7

The Cosmic State and the Divine King ........... 8

Survival of Traditions................ 14

A FEW BOOKS AND ARTICLES PERTAINING TO THE SUBJECT . . . . . 17 
At a time when the whole political system of Southeast Asia seems to be in a new cycle of development, dominated by native forces, an inquiry into the ideological foundations of native government will not be out of place and, perhaps, will even be of more than purely theoretical interest. What were the religious and philosophical conceptions which underlay and shaped the states of Southeast Asia? Are they still living forces with which we have to count or are they dead and gone? Is it possible to inoculate new ideas into old traditions, thereby avoiding a complete break with the past, a dangerous uprooting of oriental thought and culture?

In view of the limited space I shall confine myself to a discussion of some fundamental conceptions of state and kingship in those parts of Southeast Asia where Hindu-Buddhist civilization prevailed.

\section{Macrocosmos and Microcosmos}

The primary notion with which we shall have to deal is the belief in the parallelism between Macrocosmos and Microcosmos, between the universe and the world of men. According to this belief humanity is constantly under the influence of forces emanating from the directions of the compass and from stars and planets. These forces may produce welfare and prosperity or work havoc, according to whether or not individuals and social groups, above all the state, succeed in bringing their lives and activities in harmony with the universe. Individuals may attain such harmony by following the indications offered by astrology, the lore of lucky and unlucky days and many other minor rules. Harmony between the empire and the universe is achieved by organizing the former as an image of the latter, as a universe on a smaller scale.

It is well known that this astrological or cosmo-magic principle, as we may call it, originated somewhere in the Near East. It was well established in Babylonia in the 3rd millennium B.C. and there are indications that it may go back there at least as far as the middle of the 4th millennium, and possibly farther. Again, we have indications that it existed in Northwest India in the second half of the 3rd millennium. It influenced Europe in various ways and at various times, specially during the periods of Hellenism and of the Roman empire and in the Middle Ages. It is difficult to tell 
when it first reached China. Anyway it had developed there into a highly specialized system during the Chou and Han periods. It came to Southeast Asia by way of India as well as of China, and this double influence may account for its prominence there and for the strong hold it had on the minds of the peoples of Farther India and Indonesia. Its long life-span and its spread over vast regions with divergent cultures, and even more so the fact that it had to adapt itself to the locally dominant religions, to various forms of paganism as well as Hinduism, Buddhism and Confucianism, and occasionally even to Christianity and to Islam, naturally resulted in the development of numerous variants with often widely differing traits. It is with the special aspect of the cosmo-magic principle as expressed in the organization of Hindu and Buddhist kingdoms in Southeast Asia (and to some extent in their Mohammedan successors in Malaya and Indonesia), that we are here concerned.

Relation Between State and Universe

Whereas speculation pertaining to the relation between state and universe formed an important subject of ancient Chinese literature, we would look in vain for a theoretical treatise on this topic in the various literatures of Southeast Asia. ${ }^{1}$ Yet, there is overwhelming evidence of the cosmological basis of state and kingship in this area. This evidence is found in numerous passages in literature and inscriptions, in the titles of kings, queens and officials, in the "cosmic" numbers of queens, ministers, court priests, provinces, etc., in rites and customs, in works of art, in the layout and structure of capital cities, palaces, and temples. One need only put these various items together to obtain a relatively clear picture. This picture will be more complete in continental Southeast Asia, where the old forms of Buddhist state and kingship survived into very recent times. It will be hazier in the Archipelago as a result of Mohanmedan and European influences.

According to Brahmanic doctrine the world consists of a circular central continent, Jambūdvipa, surroundedey seven annular oceans and seven annular continents. Beyond the last of the seven oceans the world is closed by an enormous mountain range. In the center of Jambüdvīpa, and thus in the center of the world, rises Mount Meru, the cosmic mountain around which sun, moon

1. However, it must be taken into account that Burmese, Mon and Tha $i$ literatures are still very imperfectly known. 
and stars revolve. On its summit lies the city of gods surrounded by the abodes of the eight Lokapalas or guardian gods of the world.

In the Buddhist system, too, Mount Meru forms the center of the universe. It is surrounded by seven mountain ranges separated from each other by seven annular seas. Beyond the last of these mountain chains extends the ocean and in it lie four continents, one in each of the cardinal directions. The continent south of Mount Meru is Jambuidvipa, the abode of men. Here, too, the universe is surrounded by an enornous wall of rocks, the Chakravala Range. On the slopes of Mount Meru lies the lowest of the paradises, that of the four Great kings or guardians of the world, on its summit the second paradise, that of the thirty-three gods with Sudarsana, the city of the gods, where Indra reigns as king. Above Mount Meru tower one above the other the rest of the heavenly abodes. ${ }^{2}$

It will be seen that the Brahman and the Buddhist systems, in spite of differences in detail, agree in fundamental traits: their circular form and the arrangement in concentric zones around Mount Meru. An abbreviated image of either of them thus has the same symbolic meaning for devotees of both faiths.

The Capital as the Magic Center of Empire.

In Southeast Asia, even more than in Europe, the capital stood for the whole country. It was more than the nation's political and cultural center: it was the magic center of the empire. The circumambulation of the capital formed, and in Siam and Cambodia still forms, one of the most essential parts of the coronation ritual. By this circumambulation the king takes possession not only of the capital city but of the whole empire. Whereas the cosmological structure of the country at large could be expressed only by the number and location of provinces and by the functions and emblems of their governors, the capital city could be shaped architecturally as a much more "realistic" image of the universe, a smaller microcosmos within that macrocosmos, the empire. The remains of some of the ancient cities clearly testify to the cosmological ideas which pervaded the whole system of government. Fortunately, a number of inscriptions and some passages in native chronicles may help us in interpreting archaeological evidence.

2. There usually are twenty-six heavens in all, including those on Mount Meru, but the number occasionally varies. 
As the universe, according to Brahman and Buddhist ideas, centers around Mount Meru, so that smaller universe, the empire, was bound to have a Mount Meru in the center of its capital which would be if not in the country's geographical, at least in its magic center. It seems that at an early period natural hillocks were by preference selected as representatives of the celestial mountain. This was still the case in Cambodia in the 9 th century A.D. Yeśodharapura, the first city of Angkor, founded towards 900 A.D., formed an enormous square of about two and a half miles on a side, with its sides facing the cardinal points and with the Phnom Bakheng, a small rocky hill, as center. An inscription tells us that this mountain in the center of the capital with the temple on its summit was "equal in beauty to the king of mountains," i.e. to Mount Meru. ${ }^{3}$ The temple on Phnom Bakheng contained a Lingam, the phallic symbol of Kiva, representing the Devarája, the "God King," i.e. the divine essence of kingship which embodied itself in the actual king. More frequently the central mountain was purely artificial, being represented by a temple only. This was quite in accordance with prevailing ideas, practically every temple in Southeast Asia, whether Hindu or Buddhist, whether built of stone, brick or wood, being considered as the image of a mountain, usually, though not invariably, of Mount Meru. In ancient Cambodia a temple was quite ordinarily referred to as "giri,el mountain, and the many-tiered temples of Bali are still called Meru. The Cambodian inscriptions are very explicit with regard to such identifications. Thus, to give an example, one of them says that King Udayadityavarman II (11th century) "seeing that the Jambüdvipa had in its center a mountain of gold, provided for his capital city, too, to have a golden mountain in its interior. On the summit of this golden mountain, in a celestial palace resplendent with gold, he erected a lingam of 'Siva.e'

\section{The Lay-Out of Angkor Thom}

The actual ruins of Angkor Thom are the remains of the latest city of this site, built by King Jayavarman VII in the second half of the 12th century A.D. As Jayavarman was an adherent of Mahāyāna Buddhism, the central "mountain" in this case was a Buddhist sanctuary, which contained a large image of the Buddha Amitabha, while the four faces of Bodhisatva Lokeśvara,

3. Although Brahman and Buddhist cosmologies usually ascribe to the world a circular shape, the "cosmic" cities of Southeast Asia, with rare exceptions, affect the square form. It would take too long to explain this apparent, but not very important discrepancy. 
the "Lord of the World," adorned its numerous towers. The city was surrounded with a wall and moat forming a square almost two miles on each side, its sides being directed towards the four cardinal points. There are gates in the middle of each side and a fifth one on the East leading to the entrance of the royal palace. The towers above the gates are crowned with the same four-fold faces of Lokeśvara as those of the central temple. Thus, that smaller world, the city of Angkor, and through its means the whole Khmer empire were both put under the protection of the "Lord of the Universe." The cosmic meaning of the city was further emphasized by a curious device. The balustrades of the causeways leading over the moat to the city gates were formed by rows of giant stone figures, partly gods, partly demons, holding an enormous seven-headed serpent. The whole city thus became a representation of the churning of the primeval milk ocean by gods and demons, when they used the serpent king Vāsuki as a rope and Mount Meru as churning stick.e This implies that the moat was meant to symbolize the ocean, and the Bayon, the temple in the center of the city, on which all the lines of churning gods and demons converged, Mount Meru itself.

\section{The Capital of Burina}

Burmese chronicles say that Srikshetra (01d Prome) on the lower Irrawaddy, the capital city of the ancient kingdom of the Pyu, was built by the gods themselves with Indra at their head, built as an image of Indra's city Sudarśana on the summit of Mount Meru, with thirty-two main gates and a golden palace in its center. The remains of the city show in fact a decided attempt at a circular lay-out though complete regularity has not been achieved. It seems to have been an old custom in Burma that each of the capital's gates corresponded to one of the empire's provinces or vassal states. Thirty-two vassals or heads of provinces with the king as thirty-third in the center would of course correspond to the thirty-three gods who reside on the summit of Meru and among whom Indra is king. Thus not only the capital city but the whole empire of the Pyu must have been organized as an image of the heavenly realm of Indra.

In later capitals of Burma the square form was substituted for the circular one though the cosmological principle as such was retained. It will suffice to say a few words about Mandalay, the last capital of independent Burma, built by king Mindon in 1857 A.D. The inner city was surrounded by a

4. In the original myth Mount Mandara is used as churning stick. In Southeast Asiatic variants of the myth Mount Meru usually takes its place. 
wall and moat forming a square of more than a mile on each side, its sides facing the cardinal points. The royal palace, which occupied the center of the city, and more specifically the seven-tiered tower over the throne in the great audience hall, was identified with Mount Meru. There were three gates on each side of the city, twelve in all, and they were marked with the signs of the zodiac, thereby indicating that the city was meant to be an image of heaven with its stars spread out around the celestial mountain in its center.

\section{Cosmic Roles of King, Court and Government}

Thus the stage was set for the enacting of the cosmic roles of king, court and government. We may choose Burma as an example. There, the king was supposed to have four principal queens and four queens of secondary rank whose titles, "Northern Queen of the Palace,el "Queen of the West, el "Queen of the Southern Apartment,el etc., show that they originally corresponded to the four cardinal points and the four intermediary directions. There are indications that at an earlier period their chambers actually formed a circle around the hall of the king, thereby emphasizing the latter's role as center of the universe and as representative of Indra, the king of the gods in the paradise on the summit of Mount Meru. Sir James George Scott's observation that King Thibaw's (the last Bumnese king) failure to provide himself with the constitutional number of queens caused more concern to decorous, law-abiiding people than the massacre of his blood relations, shows how important this cosmic setting was considered to be. ${ }^{5}$ There were four chief ministers each of whom, in addition to their functions as ministers of state, originally had charge of one quarter of the capital and of the empire. They obviously corresponded to the four Great Kings or Lokapālas, the guardian deities of the four cardinal points in the Buddhist system. However, the task of representing the four Lokapālas had been delegated to four special officers, each of whom had to guard one side of the palace and of the capital. They had flags in the colors attributed to the corresponding sides of Mount Meru, the one representing Dhattarattha, the Lokapāla of the East, a white one, the officer representing Kubera, the Lokapāla of the North, a yellow flag, etc. The cosmological principle was carried far down through the hierarchy of officialdom, as revealed by the numbers of office bearers. Thus, there were four undersecretaries of state, eight assistant secretaries, four heralds, four royal messengers, etc.

5. Similarly, H. G. Quaritch Wales comments on the bad impression created among the people by the abolition of the harem systemby King Rama VI of Siam. 
Very much the same kind of organization existed in Siam, Cambodia and Java. Again and again we find the orthodox number of four principal queens and of four chief ministers, the "four pillars" as they were called in Cambodia. In Siam, as in Burma, they originally governed four parts of the kingdom lying toward the four cardinal points.

There are indications that in ancient times the cosmological structure of the state was carried even farther. I have already mentioned the probability that the old kingdom of the Pyu in Buma had thirty-two provinces or vassal states, their governors together with the king having corresponded to the thirty-three gods of the paradise on the summit of Mount Meru. Similarly the kingdom of Pegu in the 14th century had thirty-two provinces. The principality of Keng Tung, one of the largest Shan States, significantly is called "The Thirty-two Towns of the Khün," the Khün being the ruling tribe in that state. A passage in the New History of the T'ang Dynasty indicates that the kingdom of Java in the 9 th century was divided into twenty-eight provinces, their governors together with the fourministers again having numbered thirty-two high officials. This may have been a somewhat older form of the same system, in which the provinces corresponded to constellations, the twenty-eight "Houses of the Moon," and the four ministers to the guardian gods of the cardinal points. It is clear that in all these cases the empire was conceived as a image of the heavenly world of stars and gods.

Throughout the kingdoms of Farther India the system based on the compass was largely supplemented and modified by the division into offices of the right and left hand, right and left in this case referring to the place on the side of the king due to the respective office bearer on ceremonial occasions. As the king, when sitting on the throne, always faced the East, right corresponded to the South and left to the North. In Siam, for instance, there were a major and a lesser queen each of the right and of the left. Civilian officers had their places on the left of the king, officiers of the army on his right, i.e. "in the South," because the planet Mars, connected with war, was considered to be the planet of the South. Indeed, the population of Siam was divided into the two classes of the right (South) and of the left (North). The former had to render military and the latter civilian services.

Influence on Coronation Ritual

The cosmic and divine role of the king was and still is specially emphasized in the coronation ritual. In Burma the structure erected for this pur- 
pose was significantly called Thagya-nan, "Indra's Palace."e Even in the Buddhist kingdoms of Farther India the ritual is conducted by Brahmans. One of its principal features consists in the king sitting on a throne representing Mount Meru and being surrounded by eight Brahmans as representatives of the eight Lokapalas, the guardian gods of the eight directions in the Brahman world system. Moreover, four maids of honor, representing the four cardinal points, render homage to the king.

An official document published on the occasion of the coronation of King Sisowath of Cambodia in 1906 gives a slightly different explanation of the cosmic role of the king. According to this document the king is identified with Mount Meru itself, his right eye representing the sun, his left eye the moon, his arms and legs the four cardinal points, the six-tiered umbrella above his head the six lower heavens, his pointed crown the spire of Indra's palace on the summit of the Meru and his slippers the earth. This means that the king is identified with the axis of the universe. The same idea seems to be expressed by the title Paku Buwono, "Nail of the World,el of the Susuhunan of Solo in Java. However, the identification of the king with the Meru is in no way incompatible with that with Indra. Plural symbolism is very frequent in Buddhist Farther India. Thus in Burma, where the king has all the attributes of Indra, he was also identified with Viśvakarma, the divine architect and shaper of the world. Moreover, there is strong evidence of his having been identified also with the sun.

\section{The Cosmic State and the Divine King}

The cosmic state, as it existed in Southeast Asia, was intimately bound up with the idea of divine kingship. The divinity of kings was conceived in various ways according to the prevailing religion. Where Hinduism prevailed the king was considered to be either an incarnation of a god or a descendant from a god or both. Mostly it was Śiva who was thought to incarnate himself in kings or to engender dynasties. Thus in a Cham inscription of the 9 th century Uroja, the founder of the royal dynasty, is said to have been a son of Śiva. The Javanese poem Nägarakrtāgama (14th century) says bluntly that all kings are incarnations of Siva. The same poem tells us more specially that King Rájasanagara of Majapahit (1350-1339 A.D.), as proved by various portents which occurred about the time of his birth, among others a volcanic eruption, was an incarnation of Bhatāra Girinātha, i.e. Śiva as "Lord of

6. Thagya is the Burmese form of Sanskrit Sakra, the Buddhist designation for Indra. 
the Mountain.e' In the Javanese chronicle Pararaton King Krtajaya of Kadiri (13th century) on one occasion even shows himself in the super-human form of Siva with four arms and a third eye in the middle of the forehead and floating in the air. In ancient Cambodia and Champa the monarchy was intimately bound up with the cult of a lingam which was considered the seat of the divine essence of kingship. As we have seen, in Cambodia this lingam, representing the Devarāja, the "God King,è was adored in the temple in the center of the capital. The actual king was considered to be a manifestation of the divine power of the Devarāja and therefore, as the latter's visible form, the lingam, implies, obviously of Śiva himself.

However, Siva was not the only god to incarnate himself in kings. King Airlangga of Java (11th century) considered himself an incarnation of Vishnu. His memorial monument shows him in the form of Vishnu riding on the latter's man-eagle Garuda. Another noteworthy example of an incarnation of Vishnu was King Süryavarman II of Cambodia (12th century) who erected his own memorial monument as a gigantic temple of Vishnu: the famous Angkor Wat. We find further the idea of plural incarnation, also known from ancient India. Thus the Pararaton tells us that Angrok (13th century), the founder of the dynasty of Singasari and ancestor of the kings of Majapahit, was an incarnation of Vishnu, begotten by Brahma from a mortal woman, and at the same time a son of Śiva, King Krtarajasa (died 1316 A.D.), the founder of the empire of Majapahit, is immortalized by a statue representing him as Harihara, a compound of Vishnu and Siva. Even the simultaneous incarnation of Hindu and Mahayana Buddhist deities occurs. Thus, to quote only one example, the Javanese King Krtanāgara (killed 1292 A.D.) was considered as an incarnation of Śiva as well as of the Dhyāni Buddha Akshobhya. Accordingly, he became known in Javanese tradition under the name of S'iva-Buddha.

It may be added that the theory of divine incarnation could be used not only as a means to exalt the position of the legitimate king, but equally well as a justification of usurpation of the throne. Thus the above mentioned Angrok, the founder of the kingdom of Singasari, was an usurper with a long criminal career as embezzler, robber and murderer. Yet, in spite of his criminal past, he became king, according to the Pararaton, because he was an incarnation of the gods.

The theory of divine incarnation as found in Hinduism and Mahāyāna Buddhism is incompatible with the doctrine of the Buddhism of the Hinayana. This difference in tenets is clearly expressed even in the lay-out of capital 
cities. In ancient Cambodia a temple formed the center of the capital and thus the Mount Meru of city and empire. In Burma the center of the capital is invariably occupied by the royal palace, and it is this latter which is identified with Mount Meru. In ancient Cambodia either Śiva in his form as Devarāja, the eternal essence of kingship, or the Bodhisatva Lokeśvara, the "Lord of the Universe, inhabited the "central mountain" and from there pervaded the empire. Hinayānist Buddhism does not recognize an eternal deity. Indra is but the king of one of the lowest heavens, the second one from the earth. He is as little exempt from death and rebirth as any human being, except that his life lasts longer. The same may be said of the inhabitants of the higher heavens. All these "gods" of Hinayäna Buddhism should more appropriately be called angels. They have no temples and no cults. Thus it is easy to understand why in Burma no temple could be set in the center of the capital city. The adaptation to cosmological principles and the deification of the king here had to be attempted by other means. By erecting the palace in the center of the city and by identifying it with Mount Meru, the lord of the palace, i.e. the king, became automatically the representative of Indra. We might even say that he was "the Indra" of this smaller universe, the Burmese empire, but he held his place only by the magic of parallelism and he was no incarnation of the real Indra as the ancient Javanese and Cambodian kings had been incarnated of Siva and Vishnu. ${ }^{7}$ The scheme explains the great sanctity in which the royal palace was held in the Buddhist empires of Farther India. The palace was the symbol of the celestial mountain, nay, more than a mere symbol: it was "the Mount Meru" of the microcosmos Burma, or Siam, or Cambodia. Anybody nearing the palace had to show his reverence by dismounting from his horse, by shutting his parasol, by bowing to the palace spire or even kneeling down. Attempts to exact the same expressions of reverence from British envoys led to endless negotiations and frictions as the latter refused to comply with a demand which they considered humiliating. "King of the Golden Palace" was one of the most important titles of Burmese monarchs. Yet, the fact that the king "was Indra" and therefore ruler of the country only as possessor of the empire's Meru, the palace, involved great dangers. It worked as a constant temptation for would-be usurpers, be it from the ranks of the royal family or outsiders, as the occupation of the palace might be achieved by a coup-de-main with relatively small forces and usually meant the conquest

7. However, strong traces of the belief that Siva and Vishnu incarnate themselves in the king survive in the coronation rituals of Siam and Cambodia. 
of the whole empire. Many Burmese and Siamese kings therefore were virtual prisoners in their palace which they did not dare to leave for fear it might be seized by an usurper. The last king of Burma, Thibaw, preferred even to forego the important coronation ritual of the circumambulation of the capital to offering one of his relatives a chance to make himself master of the palace while he was away.

In Hinayāna Buddhism the idea of divine incarnation as justification of kingship is replaced by that of rebirth and of religious merit. It is his good karma, his religious merit acquired in previous lives, which makes a man be born a king or makes him acquire kingship during his lifetime, be it even by rebellion and murder. A typical instance is that of King Nyaung-u

Sawrahan (10th century) as told in the Glass Palace Chronical of the Kings of Burma. Nyaung-u Sawrahan, a farmer, kills the king who has trespassed on his garden and whom he had not recognized. Thereupon he is himself made king against his wish. So strong is his karma that, when one of the ministers objects to his installation, the stone statue of a guardian deity at the palace door becomes alive and kills the minister. The chronicle's comment is significant: "Although in verity King Sawrahan should have utterly perished, having killed a king when he was yet a farmer, he attained even to kingship simply by strong karma of his good acts done in the past." But the moment the karma of his past good acts is exhausted, that same stone statue which formerly had killed his adversary becomes alive again and hurls him from the palace terrace.

No merit could exceed that of a service rendered to the Buddha himself. Thus the Glass Palace Chronicle tells us that the ogre-guardian of a mountain, who had shielded the Buddha from the sun with three leaves, had received from the latter a prophecy that he would thrice become king of Burma. In the loth century he is reborn in lowly surroundings as Saleh Ngahkwe, who later becomes king by murdering his predecessor and, "being reborn from the state of an ogre, was exceeding wrathful and haughty,e indulging in gluttony and sadistic murder, till he is at last killed by his own ministers. One should think that the merit of having shaded the Buddha would have been exhaused by a life full of crimes. However, according to the Burmese chronicle, this is not so. The former mountain spirit is reborn in the 12th century as Prince Narathu who becomes king by murdering his father and brother and throughout his reign excells by bloody deeds, and in the 13th century as king Narathihapate. This leads us to a very characteristic conception of historical 
events as based on the enormous importance attributed to prophecies and portents. Indeed, one could say that, especially as far as alleged prophecies of the Buddha are concerned, in the view of Burmese historians events are not prophesied because they will happen, but they happen because they have been prophesied. The "discovery" of ancient prophecies and the "observation" of contemporary portents was a generally used expedient in Burmese politics and still forms a potent factor in what we may call political folklore.

The whole idea and outward form of kingship in Southeast Asia, and specially in the Buddhist kingdoms of Farther India, was of course based on the conception of the Chakravartin, the Universal Monarch. Now it is known that a Chakravartin is the worldly alternative to a Bodhisatva, a future Buddha. Under these circumstances the theory of rebirth and of karma was bound to induce monarchs with a very high idea of their religious merits to consider themselves as Bodhisatvas. Thus, Oung Zaya, the founder of the last dynasty of Burma, took as king the name Alaungpaya which designated him as an Embryo Buddha. His son, King Bodawpaya (1782-18319), claimed outright to be the Bodhisatva Maitreya. However, his claim was rejected by the clergy and he dropped it. A similar claim was put forth by King Taksin of Siam (1767-1782).

The theory of vocation to kingship either on the basis of divine incarnation, as in Java and ancient Cambodia, or by karma acquired in former lives, as in Burma, Siam and modern Cambodia, did not deprive that of the heredity of the right to the crown of its importance. Again and again usurpers have striven for a semblance of legitimacy by construing genealogies linking themselves either to the dynasty they had overthrown or to a dynasty which at an earlier period had governed the country. Occasionally, phantastic genealogies were constructed deriving native Southeast Asiatic dynasties from some famous dynasty of ancient India. The best known case is that of the recent kings of Cambodia who claim descent from the ancient kings of Indraprastha (Delhi). The last Burmese dynasty, founded by a village headman in the 18th century, claimed descent from the Sakya kings of Kapilavatthu, a claim which would have made them blood relatives of the Buddha himself. One type of such fictitious genealogies deserves special attention as it has a deeper meaning than merely to serve the glorification of the dynasty. The kings of Funan (3rd to 7 th centuries A.D.) and those of ancient Cambodia were said to descend from a Brahman who had come from India and from the daughter of the serpent king of 
the country. The legend is still alive in Cambodia, the Brahman being replaced in the modern version by a prince of Southeast Asia. The meaning is clear. The Nägas, the serpent demons, are the original masters of the soil. By his descent from the daughter of the Näga king the monarch had a legitimate claim to the soil of his kingdom which, in theory at least, thereby became his personal property. A Chinese report tells us that in the 13th century the people of Cambodia believed that the king nightly cohabited with the serpent goddess of the soil who visited him in his palace in human form. Obviously he was thought thereby to renew the connection between himself and the soil of his kingdom. Thus the king in ancient Cambodia, as an incarnation of the Devarája and as a descendant and at the same time spouse of the goddess of the soil, formed a real magic center linking the empire to the divine forces of the heavens as well as of the earth.

Any account of the conceptions of state and kingship in Southeast Asia would be incomplete without at least mentioning the great importance of the regalia. Some of these, as the umbrella and the crown, have cosmological meaning as noted above. Moreover, the umbrella was thought to be the seat of a protective genius who favored the king with his advice and who in critical moments might even actively intervene on behalf of the dynasty. Other regalia are thought to be possessed of magic forces, such as the royal sword of Cambodia which, it is believed, if drawn from its scabbard without the prescribed ritual, would bring disaster upon the country. This magical character of the regalia is even more stressed in the Malay Peninsula and in Indonesia. It culminates in the curious conception prevalent among the Bugis and Makassarese of Celebes, according to which it is really the regalia which reign, the prince governing the state only in their name.

The deification of the king, while raising him to an almost unbelievably exalted position with regard to his subjects, has in no way succeeded in stabilizing government, rather the contrary. As explained above, the theory of divine incarnation, and even more so that of rebirth and of karma, provided an easy subterfuge for usurpers. The fact that the relatively easy task of seizing the palace, as in Burma and Siam, or of seizing the regalia, as in certain parts of Indonesia, often sufficed to be accepted as king by the whole nation, was bound to act as an additional incitement to rebellion. Moreover, the immense power and the lack of restrictions which the king enjoyed invited abuses which in the end made the monarch obnoxious to his subjects and hastened his downfall. 
To this came the vagueness of the rules of succession. Sometimes the king himself chose his successor. Sometimes the ministers appointed a prince as king. Then again the queens unofficially but efficiently exercised their influence in favor of a prince of their choice. Often the crown simply fell to the prince who was the quickest to seize the palace and to execute his brothers. Under these circumstances it is no wonder that the empires of Southeast Asia from the very beginning were torn by frequent rebellion, often resulting in the overthrow of kings or even dynasties. The earliest reports we have, those from Chinese sources on the kingdom of Funan, reveal such conditions to have existed as early as the 3rd century A.D. If there was a long period of oppression and unrest, rebellion and its concomitant, dacoity, could become practically a popular tradition which it was difficult to eradicate. Such was the case, for instance, in Burma during the 18th and 19th centuries, and it is in the light of such a past that recent events in that country ought to be seen.

Survival of Traditions

In order to realize how deeply the populations of Farther India were affected by the cosmological structure of the state one need only think of the division of the Siamese people into the classes of the right and of the left which, not long ago, determined the services each person was obliged to render to the state. Moreover, it must not be forgotten that the cosmomagic principle as applied to the state really forms only part of a much wider complex and resulted from a conception of the universe and of human existence which regulated, and to a large extent still regulates, also the private lives of individuals. When in Siam and Cambodia people wore cloths of different color on different days of the week according to the color ascribed to the planet for whom the day is named, or when in Burma before any important undertaking they examine their horoscope and the lore of lucky and unlucky days, or when they kneel down for prayer on that side of the pagoda which in the cosmological system corresponds to the planet of the weekday on which they were born, they act on the same principle which governed the structure of their empires, their ideas of kingship and the ritual of their royal courts. It is clear then that the cosmo-magic ideas, until a very recent past, had an extremely strong hold on the minds of the people.

Is all this a crumbling structure, giving way under the impact of modern civilization or may it still influence the political activities of the peoples concerned? The question is not easily answered. Information on this point is scarce. There are, however, a few indications. 
We have it on the authority of H. G. Quaritch Wales that the people of Siam, around 1930, still held the ancient state ceremonies in high esteem, those ceremonies which to a large extent are governed by cosmological ideas. One may ask oneself, how much of this old tradition may have been at the bottom of the royalist rebellion of 1933.

In Burma the following cases may be considered as significant. In 1397 twelve years after the annexation of Upper Burma by the British, a Buddhist monk, $U$ Kelatha, fell in love with a princess of the dethroned dynasty who promised to marry him if he became king of Burma. There followed the usual dreams or visions which revealed to him that in a former life he had been a Burmese prince and, moreover, that he would be king the moment he sat on the throne of the palace in Mandalay. With eighteen followers, all armed with swords only, he rushed through the city gates and tried to reach the royal palace, at that time seat of the English club. A few English officers armed with hunting rifles made an end to his attempt. The incident proves the extreme vividness of cosmo-magic ideas at the close of the 19th century. As we have seen, whoever held the palace, the Mount Meru of the Burmese empire, thereby became the representative of Indra and the king. It is completely in accord with the cosmo-magic way of thinking that $U$ Kelatha and his followers believed the mere occupation of the throne would make him automatically lord of the whole empire.

Unfortunately, very little authentic information is available on the Burmese rebellion of 1930-31. However, the following detail, as revealed at the time by newspaper dispatches, is significant. One of the first actions of Saya San, the leader of the rebellion, was to build a "palace", in reality a bamboo hut somewhere in the jungle, with an inscription designating it as the "Palace of the Buddhist King.e" It is, of course, very easy to ridicule such pretensions, but it is more important to understand them. We have seen how inseparable king and palace were according to Burmese ideas. No kingdom could exist without a palace representing Mount Meru and forming its magic center, and the king, the "Lord of the Golden Palace", was king in the first line by his possession of the palace. Saya San's action in building a palace, a magic center for his embryonic empire, therefore corresponds closely to that of $U$ Kelatha when he wanted to seat himself on the throne of the palace in Mandalay.

The story of the Myinmu rebellion of 1910, as told by Paul Edmonds in his book, Peacocks and Pagodas, if it does not directly contribute to our knowledge of cosmo-magic ideas, at least gives a significant instance of the power of the belief in rebirth, prophecies and portents. A young man of eighteen years, 
Maung Than, was returning from work in the fields smoking a cigar. Some people who passed him thought they saw smoke issuing from his arms. They talked about it in the village and the rumor reached some elders who were familiar with an old tradition according to which a former king of Burma, Chanyeiktha, would be reborn in the shape of a youth who had the power of making smoke issue from his armse "Other signs and portents were looked for. Needless to say, they were forthcoming. The griffins at the foot of an old pagoda were seen to shake; gold showers fell on another pagoda; and everywhere omens multiplied which pointed to young Maung Than as the long-foretold reincarnation of King Chanyeiktha." Maung Than entered into the spirit of the game and put forth the usual claims of being invulnerable and of possessing the power to make himself invisible. With a crowd of a thousand followers armed with swords and spears he attacked the police station at Myinmu but was repulsed and eventually captured.

One may ask whether there is any possibility of this same conception becoming the basis of future constructive developments. The question is difficult to answer. Orientals with western education, and above all the leaders of nationalist movements, tend to disregard and to despise the "superstitions" which governed their nations in the past. Yet, there is the vast mass of the common people, grown up in the old traditions, people to whom the modern ideas of democracy and representative government mean little or nothing and who cannot be educated overnight. A sudden complete break of cultural traditions has almost always proved disastrous to national and individual ethics and to the whole spirit of the peoples affected. A compromise between old and new conceptions therefore would seem desirable. Many, at least, of the outward expressions of the old ideas could easily be kept intact and gradually filled with new meaning, without in the least impairing educational and material progress. After all, the case of Japan shows that an idea decidedly more primitive than that of the cosmic state and less adaptable to ethical reinterpretation than the latter, the beleief in the descent of the Mikado from the Sun Goddess (or at least the fiction of such belief) may very well survive and coexist with all the refinements of medern science and technique. The current problems of Southeast Asia hitherto have been discussed almost exclusively from the point of view of economics and of political science. It would be a grave mistake to disregard the importance of native culture and tradition for a future satisfactory reorganization of that region. 
A FEW BOOKS AND ARTICLES PERTAINING TO THE SUBJECT

F.D.K. Bosch, "Het, lingga-heiligdom van Dinaja," Tijdschrift voor Indische taal, land- en volkenkunde, 64 (1924), 227-91.

George Coedes, "Note sur l'apothéose au Cambodge, é Bulletin de la commission archeologique de l'Indochine, (1911), 38-49.

Louis Finot, "Sur quelques traditions Indochinoises,el Ibid., pp. 20-37.

Karl Döhring, Siam, 2 vols. Darmstadt, 1923.

The Glass Palace Chroniele of the Kings of Burma. Translated by Pe Maung

Tin and G. H. Luce. London, 1923.

Robert Heiee-Geldern, "Weltbild und Bauform in Südostasien,ë_Wiener Beiträge zur Kunst- und Kulturgeschichte Asiens, 4 (1930), 28-78.

Adhémard Leclere, Recherches sur le droit public des Cambodgiens. Paris, 1894.

, "Cambodge: Fêtes civiles et religieuses," Annales du Musée Guimet: bibliotheque de vulgarisation, 42 (Paris) 1917.

Paul Mus, Barabudur: Esquisse d'une histoire du Bouddhisme fondée sur la critique archéologique des textes. 2 vols. Hanoi, 1935.

J. George Scott, assioted by J.eP. Hardienan, Gazetteer of Upper Burma and the Shan States, Part I, Vol. I, pp. 85-195 "Palace customs and Burma under native rule"; pp. 469-515 "Government and administration under the Burmese kings, ë Rangoon, 1900.

Walter William Skeat, Malay Magic. London, 1900

H. G. Quaritch Wales, Siamese State Ceremonies. London, 1931.

- Ancient Siamese Government and Administration. London, 1934. 